\title{
RISK STRATIFICATION IN SEPSIS: WHAT WE CAN DO IN THE EMERGENCY ROOM?
}

\author{
Sebastian Dogaru1, Caius Bogdan Teusdea1, Florea Purcaru² \\ ${ }^{1}$ Emergency Department, "Dr. Carol Davila" Central Emergency University Military Hospital, \\ Bucharest, Romania; \\ ${ }^{2}$ University of Medicine and Pharmacy, Craiova, Romania \\ Corresponding author: \\ Sebastian Dogaru \\ E-mail: sebidogaru@hotmail.com
}

Motto:

"Si vis pacem, para bellum" (Ifyou want peace, prepare for war)

\begin{abstract}
Sepsis is a life-threatening organ dysfunction due to a dysregulated host response to infection and it is an important global health problem. After the Sepsis 3 definition, sepsis is only the tip of the iceberg. Only when is life-threatening, an infection is declared sepsis, so the rapid medical intervention is paramount. As the sepsis is a so important medical condition in daily clinical practice, many scores and biomarkers were studied in order to have a better risk stratification in early phases of an infection. By design, some scores were intended to be used in Emergency Departments (ED), Intensive Care Units (ICU), or in specific wards.

Ideally, the intervention should take place as rapid and earlier as possible. A possible research direction should be based on a rapidly, low-resources, none or minimum equipment requested for measuring parameters for determining a EWS (increased sensitivity) used with a biomarker (rapidly determined) for gaining specificity in order to buy time, further used to reduce the length of stay in ICU and mortality. Verified and revised scores as NEWS2 and biomarkers such as procalcitonin and presepsin offer a research direction to be explored.
\end{abstract}

Keywords: sepsis, biomarkers, scores.

\section{Rezumat}

Sepsisul este o disfuncție de organ amenințătoare de viață, cauzată de răspunsul inadecvat al gazdei la infecție, și reprezintă o problemă importantă de sănătate la nivel mondial. După definiția Sepsis 3, sepsisul este doar vârful aisbergului. Doar atunci când o infecție pune viața în pericol este declarată sepsis, astfel încât intervenția medicală rapidă este primordială. Deoarece sepsisul este o afecțiune medicală atât de importantă în practica clinică zilnică, au fost studiate multe scoruri și biomarkeri în scopul unei stratificari mai bune a riscului în fazele 


\section{INTERNAL}

\section{General Reviews}

incipiente ale unei infecții. Unele scoruri au fost destinate utilizării în departamentele de urgență, în unitățile de terapie intensivă sau pe secții specifice.

În mod ideal, intervenția ar trebui să aibă loc cât mai rapid și mai devreme. O posibilă direcție de cercetare ar trebui să vizeze un scor de alarmă timpuriu ai cărui parametri pot fi determinați rapid, cu resurse reduse, necesitând echipament minim, folosit cu un biomarker (determinat rapid), pentru a câștiga timp, utilizat în continuare pentru a reduce durata șederii pe secția terapie intensiva și a mortalității. Scorurile verificate și revizuite în acest sens și biomarkerii precum procalcitonina și presepsina pot reprezenta direcții de carcetare în acest sens.

Cuvinte cheie: sepsis, biomarkeri, scoruri.

Sepsis is a life-threatening organ dysfunction due to a dysregulated host response to infection $^{(1)}$ and is an important global health problem. In the USA, sepsis is the most common cause of in-hospital deaths and costs more than US\$24 billion annually ${ }^{(2,3)}$. It is estimated to affect more than 30 million people worldwide every year, potentially leading to 6 million deaths ${ }^{(4)}$. The burden of sepsis is most likely highest in low- and middle-income countries.

As new pathogens arise (SARS, coronaviruses) and the growing worldwide fast circulation of people means that rapid spreading is not a matter of if, but of a when will it happen to you and your medical environment. Asymmetrical warfare and terrorist threatening are also a factor to be considered. From a medical point of view, intrahospital infections with pathogens that are increasingly multidrug resistant and antibiotics seen as a rapidly exhausting resource ${ }^{(5)}$, sepsis is seen as an even more important problem.

After the Sepsis 3 definition, sepsis is only the tip of the iceberg. Only when is lifethreatening, an infection is declared sepsis. But the infection is a continuum. An initial infecting aggression can be locally managed and rejected or it can further propagate. A generalized response leads to a systemic inflammatory response syndrome which only when becomes life-threatening is declared sepsis. To be declared, some conditions must be met (qSOFA criteria), assigning one point for low blood pressure (SBP $\leq 100 \mathrm{mmHg}$ ), high respiratory rate ( $\geq 22$ breaths per $\mathrm{min}$ ), or altered mentation (Glasgow coma scale $<15)$. The score ranges from 0 to 3 points. The presence of 2 or more qSOFA 
points near the onset of infection was associated with a greater risk of death or prolonged intensive care unit stay ${ }^{(1)}$. Based upon these findings, the Third International Consensus Definitions for Sepsis recommended qSOFA as a prompt and simple tool to identify infected patients outside the ICU who are likely to be septic.

Sepsis 2 definition and management rules stressed out that time is of critical importance. Early targeted therapy implied that a resuscitation bundle for the first 6 hours and a management bundle for the first 24 hours should be used. Although changing the definition, Sepsis 3 definition (2016) with 2018 Sepsis Update indirectly said the same thing. The rapid medical intervention is paramount because what it should have been done in the first 3-6 hours must be done in one hour now.

Another definition or some other tools with greater prognostic value should be used in order to permit an earlier intervention with greater success, before becoming a life or death situation. This would mean that resources would be spared and subsequently increasing efficacy would save lives. Diagnosing sepsis only when it becomes a life-threatening situation and having only a short time span to act should be somehow predicted beforehand- time is a valuable resource and more time at your disposal would mean better results.

The ideal prognostic score should be easy to calculate, preferably without the need of laboratory results or if necessary, to be rapidly obtained and should show good predictive value.

As the sepsis is a so important medical condition in daily clinical practice, a many scores were developed and some biomarkers were studied in order to have a better risk stratification in early phases of an infection.
Studies have proved that clinical deterioration is often forecasted by changes in vital signs up to 6 to 24 hours $^{(6,7)}$. Consequently, several scores were developed to identify the patients at risk to deteriorate. By 2015 over 36 Early Warning Scores (EWS) were expected to accurately forecast the prognostic. By design, some scores were intended to be used in ED (Rapid Emergency Medicine Score- REMS), in specific patient groups (Mortality in Emergency Department Score- MEDS in ED patients with sepsis, CURB-65 in patients with pneumonia) or in specific wards (Acute Medical Unit- AMU). Also, there are developed scores focusing on earlier detection as Systemic Inflammatory Response Syndrome (SIRS), Modified Early Warning Score (MEWS), Rapid Acute Physiology Score (RAPS), or National Early Warning Score (NEWS) first released in 2012 and updated in December 2017, which advocates a system to standardize the assessment and response to acute illness (NEWS 2).

As a rule one can observe the different approach of the score; there are scores intended to be of earlier use and as a consequence with high sensitivity, low specificity, but with an increased time available for intervention if appropriate (NEWS, MEWS, RAPS, REMS) or scores of severity, implying organ impairment, with a cost, reducing the time available for intervention meaning increased specificity and low sensitivity (qSOFA, MEDS). The first ones are for use in wards, lower capability medical units, and the latter for use in higher capability settings (ED). ICU has its own, more elaborated scores (SOFA, APACHE) based on more time requesting, laboratory results. Simplifying, the diagnosis of sepsis for rapid recognition as high probability diagnosis in ED and prehospital conditions, with regard to 


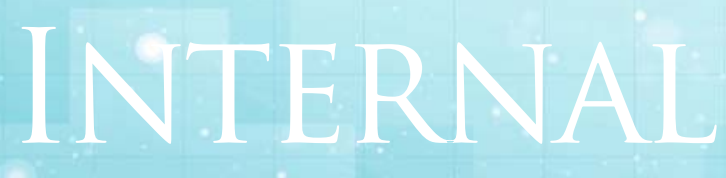

General Reviews

the low-income countries with lower medical capability, qSOFA is far to be perfect. It does not allow too much time for efficient medical intervention and after all it is a score of severity and of probability, not for diagnosis; even one qSOFA point does not guarantee your patient state is not going to further deteriorate.

In other words, the infection and its severe complications, sepsis and septic shock are still lacking comprehensive understanding. Although huge steps were made, there are still no well-established inflexion points where decisive actions would make the difference, if applied. The scientific effervescence in this domain says a lot. In the past 10 years only, over 200 biomarkers were studied in order to detect an earlier predictor for the progression of sepsis, according to Sepsis-2 definitions definitions (severe sepsis, septic shock). Some authors even considered necessary to use 2 biomarkers for better estimating the infection status. Sometimes difficult and expensive to determine, some biomarkers were more promising than the others, so POCT (Point of Care Testing) devices were conceived, offering the results in less than 20 minutes.

In our opinion, ideally, the intervention should take place as rapid and earlier as possible. A possible research direction should be based on a rapidly, low-resources, none or minimum equipment requested for measuring parameters for determining a EWS. Sepsis-3 gives you the probability of death/ ominous prognostic when the patient status is severely affected. Some rapidly determined score with a cost-efficient biomarker added to this would buy time for earlier intervention, save lives and decrease hospitalization. This combination, EWS and biomarker, should accurately predict, with both sensitivity and specificity, the possibility of an infection to further deteriorate to sepsis after Sepsis-3 definition, without endangering the survival or the life span.

Supposing that an infection is a problem only when becomes life-threatening, minimizes the importance of the infection and his future evolution ${ }^{(8)}$. Having increasingly older and sicker patients with multiple associated chronic conditions means that you will not treat only a wreaking havoc out-of-control infection, but a complex patient with minimum resources to be mobilized. So, the time is critical again. Before becoming almost not manageable, an infection gives you a lot of clues which can give early and prognostic clues to buy time.

Seen in perspective, the history repeats itself. A few years ago, the myocardial infarction was a great mortality condition. Treating only the ST elevation because it has a greater specificity than the angina pectoris was not an option for the cardiologists. Only after recognizing the great prognostic value of 
angina pectoris, great progress was achieved. Increased sensibility of an early warning sign with the aid of a specific biomarker, troponin, bought time for the specific intervention, angiography (inflexion point). The same elegant principle should be used, in sepsis an early warning sign/scoreincreased sensibility, low specificity- used with a biomarker which will increase the specificity should buy time for specific interventions to save more lives.

It is now known that qSOFA too late predicts the patient altered status (median of 5 hours as a predictor of death or ICU transfer), while SIRS precedes the same events by minimum 17 hours $^{9}$. After all, SOFA and qSOFA are severity scores and better predictors of death than the SIRS which does not imply an organ injury/ impairment. So, the specificity increases, but at a time cost. Studies made before 2016 Sepsis-3 criteria showed that early administration of fluids and antibiotics decreased the incidence for sepsis and septic shock, of mortality and underlines the importance for early recognition of sepsis. Indirectly, by adopting 2018 Sepsis Update, the medical community admits that the early medical intervention is paramount.

The optimal time for intervention is probably somewhere between. Not every SIRS progress to sepsis and sepsis is sometimes too late for the patient. Using a combination of a EWS and a biomarker is expected to offer the optimal proportion between sensitivity and specificity for an intervention to be considered before an organ impairment to further progress to an organ injury or before an injured organ/ system to become lifethreatening.

While developed for minimal resources, qSOFA remains a score of severity which can be prevented by earlier intervention. Easy to be determined with minimal resources it has its advantages. Designed to be applied in minimal resources environments, prehospital settlements, battlefields or third world countries, sepsis can be prevented in more evolved medical capability systems. Nowadays in Romania, there are POCT devices in EDs, so a more appropriate action should be used. A rapid blood count and a biomarker determination can be done in less than 20 minutes- the necessary time for a proper anamnesis.

Two biomarkers are now used in daily practice: procalcitonin and presepsin. While procalcitonin have higher values after surgical interventions, cardiogenic shock, graft versus host disease, immunotherapy or acute pancreatitis, trauma or burns without any infection being present, so it is not so specific, it is used for diagnosing infection with some accuracy. Presepsin, in fact a soluble CD14 protein ( $\mathrm{SCD} 14$ ) normally is found in small quantity in blood but increases in bacterial infection and is secreted by monocytes after phagocytosis. Their levels are somewhat biased by renal impairment, in other words by creatinine clearance. On the other side, as an early warning score, NEWS released in 2012 and audited in UK for over five years in all medical facilities was revised, improved and used as NEWS 2 from 2017. NEWS2 as a EWS and a POCT biomarker as PSP or PCT are an interesting future direction for research.

\section{Conclusions}

Very high costs and still increased mortality in sepsis after the new definitions, tells us that much is to be done. With complex pathophysiology and still not completely understood mechanisms, sepsis is a medical condition that is increasingly met in older and more fragile patients. Time is always critical 


\section{INTERNAL}

\section{General Reviews}

and particularly important when dealing with sepsis. In our opinion, combining a nonspecific early warning score (NEWS2) ${ }^{(10)}$ with a specific biomarker for sepsis (presepsin- soluble fragment of CD14, procalcitonin- peptide precursor of the hormone calcitonin) is a valuable research direction to explore.

\section{References}

1. Singer M, Deutschman CS, Seymour CW, et al. The third international consensus definitions for sepsis and septic shock (Sepsis-3). JAMA 2016; 315: 801-10

2 Liu V, Escobar GJ, Greene JD, et al. Hospital deaths in patients with sepsis from 2 independent cohorts. JAMA 2014; 312: 90-92.

3. Torio CM, Moore BJ. National inpatient hospital costs: the most expensive conditions by payer, 2013. May, 2016. https://www.hcup-us.ahrq.gov/ reports/ statbriefs/sb204-Most-Expensive-HospitalConditions.pdf (accessed Nov 6, 2019).

4. Fleischmann C, Scherag A, Adhikari NK, et al. Assessment of Global Incidence and Mortality of Hospital-treated Sepsis. Current Estimates and Limitations. Am J Respir Crit Care Med 2016; 193(3):
259-72.

5. Laxminarayan $R$, Matsoso P, Pant $S$, et al. Access to effective antimicrobials: a worldwide challenge. Lancet 2016; 387(10014): 168-75

6. Hillman, K.M., Bristow, P.J., Chey, T. et al. Duration of life-threatening antecedents prior to intensive care admission. Intensive Care Med 28, 1629-1634 (2002). https://doi.org/10.1007/s00134-002-1496-y

7. Schein RMH, Hazday N, Pena M, Ruben BH, Sprung CL. Clinical Antecedents to In-Hospital Cardiopulmonary Arrest. Chest. 1990;98(6):1388-1392. doi:https:// doi.org/10.1378/chest.98.6.1388

8. Simpson SQ. SIRS in the Time of Sepsis-3. Chest. 2018;153(1):34-38. doi:https://doi.org/ 10.1016/j.chest.2017.10.006

9. Churpek, Matthew \& Snyder, Ashley \& Han, Xuan \& Sokol, Sarah \& Pettit, Natasha \& Howell, Michael \& Edelson, Dana. (2016). qSOFA, SIRS, and Early Warning Scores for Detecting Clinical Deterioration in Infected Patients Outside the ICU. American Journal of Respiratory and Critical Care Medicine. 195. 10.1164/rccm.2016040854OC.

10. NEWS2 charts reproduced from: Royal College of Physicians. National Early Warning Score (NEWS) 2: Standardising the assessment of acute-illness severity in the NHS. Updated report of a working party. London: RCP, 2017. 